\title{
Studies on the Morphometry of Macrobrachium nobilii (Decapoda, Palaemonidae)
}

\author{
Pitchaimuthu Mariappan* and Chellam Balasundaram \\ Crustacean Aquaculture and Behaviour Unit - CRABU; Department of Animal Science; Bharathidasan University; \\ mnobilii@rediffmail.com; Tiruchirapalli; 620024; India
}

\begin{abstract}
Fourteen morphometric characters of Macrobrachium nobilii (Henderson and Matthai, 1910), a freshwater prawn were measured from 72 males and 66 females collected at random in field. The growth constant (b) of total length and weight for male (4.28) and female (3.02) differed significantly $(P<0.05)$. Comparison of slopes and elevations of regressions between sexes indicated significant difference in all the studied dependent parameters with carapace length $(X)$, except with carapace width $(Y)$. In males, major and minor chelipeds showed positive allometry while in females the growth was isometric.
\end{abstract}

Key words: Allometry, cheliped, freshwater prawn, length-weight, Macrobrachium nobilii

\section{INTRODUCTION}

Allometric or relative growth pattern of various decapod crustaceans has been studied widely (Hartnoll, 1978; Finney and Abele, 1981; Sumpton, 1990; Sarda and Cartes, 1997; Munio et al., 1999), including genus Macrobrachium (Holthuis, 1950; Koshy, 1973; Jayachandran, 1998; Mossolin and Bueno, 2003). Allometric growth is determined by treating one variable (X) as reference or independent dimension and comparing it with another dependent variable (Y) (Snedecor and Cochran, 1967). In Crustaceans, structures such as chelate legs in males, pleopod and abdominal width in females grow abruptly on attaining sexual maturity. This phenomenon is utilized to differentiate the mature and immature population in many decapods, which are not sexually dimorphic (Pinheiro and Fransozo, 1998; Munio et al., 1999). Though the studies on the growth of chelipeds, especially that of Brachyuran has drawn detailed attention (Hartnoll, 1982), similar studies on individuals segments of chelipeds are scanty (Jayachandran et al., 1996). The ratio between cheliped length and carapace length is species specific and this character has been subjected to detailed statistical analyses in taxonomy studies (Holthuis, 1950; Jayachandran, 1998). In caridean prawns such as Macrobrachium, the chelipeds are taxonomically important (Chace and Bruce, 1993). Recently, Suzuki and Kusamura (1997) differentiated $M$. nipponese from $M$. formosense on the basis of length and width of dactyl of second pereiopod. Such investigations are also essential to establish morphotypes in species such as $M$. rosenbergii. Moreover, the genus Macrobrachium contains more than 100 species; their identification is quite difficult due to great morphological variations (Koshy, 1971). In India, the farmers still depend

\footnotetext{
* Author for correspondence
} 
upon natural seed supply for stocking their ponds. Hence, knowledge on the identity of the species chosen for culture is an impelling necessity to eliminate mixing of species (Mariappan and Balasundaram, 1999). With this view, the study was conducted to find out length-weight relationship, growth pattern of chelipeds and segments of an endemic freshwater prawn Macrobrachium nobilii (Henderson and Matthai, 1910). Despite its small size, the culture of $M$. nobilii is encouraged due to its commercial and nutritional value (Mariappan et al., 2002; 2003)

\section{MATERIAL AND METHODS}

A total of 72 males and 66 females of Macrobrachium nobilii were collected from Grand Anicut, near Tiruchirpalli $\left(10^{\circ} 50^{\prime} \mathrm{N} ; 78^{\circ} 43^{\prime} \mathrm{E}\right)$ in river Cauvery. It is the fourth largest river in Indian Peninsula, which flows a distance of about $1171 \mathrm{kms}$. Total length, cephalo thoracic length, carapace width, carapace length, major and minor chela length, total weight of the animal and individual weight of chelae were calculated. Length of the individual segments of major and minor chela was also measured (Fig. 1).

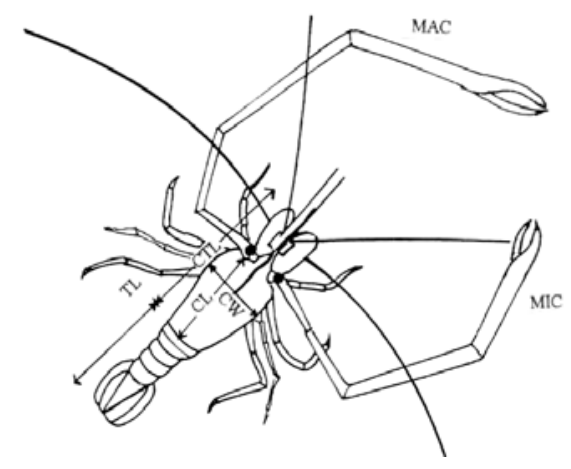

Figure 1 - Morphometry measurements of Macrobrachium nobilii. TL-Total length, CL-Carapace length, CTL-Cephalothorax length, CW-Carapace Width, MAC-Major Chela, MIC-Minor Chela.

The first two proximal segments i.e. coxa and basis were ignored since their length was small when compared to the total length of chelipeds (see also Nagamine and Knight, 1980; Kuris et al., 1987). Measurements were taken to the nearest $0.1 \mathrm{~mm}$ by using a Vernier caliber. Major and minor chelipeds were individually weighed in an electronic monopan balance $( \pm 0.001 \mathrm{~g})$.

Since sexual dimorphism is prominent in adult, $M$. nobilii, the data for males and females are analyzed separately to fit regression lines to study the allometeric growth pattern within and between sexes. In this study, the carapace length referred as $\mathrm{CL}$ was used as the reference dimension since as a taxonomic character CL was more reliable than cephalothorax length (CTL) which often got damaged due to various factors (Grandjean et al., 1997).

Crustacean allometric growth is defined by $\mathrm{y}=\mathrm{ax}^{\mathrm{b}}$; this equation after $\log$ linearization yields $\log \mathrm{y}=$ $\log a+b . x$ which eases the application of the results (Hartnoll, 1982). In the present study also the data were $\log$ transformed before computing the regression equation (Sokal and Rohlf, 1981). In this context the derived slope value $b$ referred as allometric growth constant was designated as: 1) isometric when 'b' ranged from 0.9 to 1.1 (Kuris and Carlton, 1977), 2) positive if more than 1 and 3) negative if less than 1 (Tessier. 1960; Hartnoll, 1982). The variation between slopes and elevations of the regression lines within and between sexes were tested by analysis of covariance (Sndecor and Cochran, 1967). The variations among major and minor chela length and weight within and between sexes were tested separately.

\section{RESULTS}

Seventy-two males (total length: $46-77 \mathrm{~mm}$ ) and 66 females $(30-71 \mathrm{~mm})$ were used for the morphometric study. Male $M$. nobilii had a minimum body weight of $1449 \mathrm{mg}$ and a maximum of $12676 \mathrm{mg}$. The body weight of female ranged from $336 \mathrm{mg}$ to $7178 \mathrm{mg}$. In general, growth was manifested through size increment, which could be measured by increase in volume or weight (Kunju, 1978). Generally, the weight of crustaceans varies with the cube of the length (Jayachandran and Joseph, 1988). The increase in weight of both sexes of $M$. nobilii as measured by growth constant ' $b$ ' was higher for males (4.28) than females (3.02), indicating the positive allometric growth in this species. Subsequently, ANCOVA was performed to compare the slope and elevation of regression lines between males and females. The results indicated that there was a significant difference 
$(\mathrm{P}<0.001)($ Table 1) between sexes for all the chosen variables except for carapace width and total weight $(\mathrm{P}>0.05)$. In males, the body weight, chelae length and weight with reference to carapace length indicated positive allometric growth while other parameters such as total length, cephalothorax length and carapace width showed negative allometry (Table 1 ).

\section{Chela Growth}

In females, the growth pattern of major and minor chela length was isometric. In males, there was a remarkable difference in the pattern of length increment between major and minor chela $(\mathrm{P}<0.001)$ but no such difference prevailed either in chela weight in males or length and weight of females $(\mathrm{P}>0.05)($ Table 2$)$. For both sexes the ratio between major and minor chela length and weight were calculated. The length ratio varied from 1.15 to 1.58 and that of weight varied from 0.87 to 2.42 for males. For females, the chela length ranged from 1 to 1.43 and the weight ratio ranged from 1 to 2.08. The change in the chela length (major /minor) remained constant $(\mathrm{P}>0.05)$ in male and female. A similar trend was observed with reference to major and minor chela weight ratio for females. However, for males there was a significant inverse relationship between major chela weight/minor chela weight ratio and carapace length.

Table 1 - Macrobrachium nobilii: Analysis of Covariance (ANCOVA) to test the slopes (b) and elevations of regression equation for males $(\mathrm{n}=72)$ females $(\mathrm{n}=66)$.

\begin{tabular}{|c|c|c|c|c|c|c|}
\hline \multirow[t]{2}{*}{ Characters } & \multicolumn{2}{|c|}{ Regression Equation } & \multicolumn{2}{|c|}{ Comparison of } & \multicolumn{2}{|c|}{ Allometry } \\
\hline & Male & Female & Slope & Elevation & Male & Female \\
\hline \multicolumn{7}{|c|}{ Growth in relation to carapace length } \\
\hline Total length & $1.022+0.608 . X$ & $0.87+0.702 . \mathrm{X}$ & $1.61^{*}$ & $237.53 * * *$ & 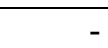 & - \\
\hline Cephalothorax length & $0.359+0.862 . \mathrm{X}$ & $0.291+0.885 . \mathrm{X}$ & $10.44 * * *$ & $40.59 * * *$ & - & - \\
\hline Carapace width & $-0.011+0.862 . \mathrm{X}$ & $-0.054+0.886 . X$ & $0.7^{\mathrm{NS}}$ & $75.25 * * *$ & - & - \\
\hline Major chela length & $-0.534+1.92 . X$ & $0.395+0.972 . X$ & $32.28 * * *$ & $109.15^{* * *}$ & + & 0 \\
\hline Minor chela length & $-0.61+1.88 . X$ & $0.424+0.905 . \mathrm{X}$ & $37.12 * * *$ & $157.06^{* * *}$ & + & 0 \\
\hline Major chela weight & $-3.074+4.51 . X$ & $-0.994+2.388 . X$ & $25.18 * * *$ & $236.18 * * *$ & + & + \\
\hline Minor chela weight & $-4.255+5.371 . X$ & $-1.176+2.44 . X$ & $49.17 * * *$ & $293.86 * * *$ & + & + \\
\hline Chela weight & $-3.264+4.865 . X$ & $-0.76+2.4 . X$ & $53.35 * * *$ & $323.03 * * *$ & + & + \\
\hline Total weight & $8.022+2.929 . X$ & $5.012+2.853 . \mathrm{X}$ & $0.10^{\mathrm{NS}}$ & $193.87 * * *$ & + & + \\
\hline
\end{tabular}

* Statistically significant $(\mathrm{P}<0.05): \mathrm{F}_{70,64}=1.502$

$* * *$ Statistically significant $(\mathrm{P}<0.001): \mathrm{F}_{70,64}=2.166$

NS Statistically not significant $(\mathrm{P}>0.05): \mathrm{F}_{70,64}$

Table 2 - Macrobrachium nobilii: Summary of Analysis of Covariance results obtained between major and minor chelae length and weight in relation to carapace length.

\begin{tabular}{|c|c|c|c|c|c|}
\hline Variations & Reduction & Df & SS & MS & $\mathbf{F}$ \\
\hline \multicolumn{6}{|l|}{ Male chela length } \\
\hline Between chelae & 1.95 & 70 & 4.21 & 0.06 & $8.36 * * *$ \\
\hline Within chelae & 1.88 & 70 & 0.50 & 0.007 & \\
\hline \multicolumn{6}{|l|}{ Male chela weight } \\
\hline Between chelae & 10.82 & 70 & 2.05 & 0.029 & $0.75^{\mathrm{NS}}$ \\
\hline Within chelae & 15.34 & 70 & 2.74 & 0.039 & \\
\hline \multicolumn{6}{|l|}{ Female chela length } \\
\hline Between chelae & 0.55 & 64 & 0.46 & 0.007 & $1.49^{\mathrm{NS}}$ \\
\hline Within chelae & 0.48 & 64 & 0.31 & 0.005 & \\
\hline \multicolumn{6}{|l|}{ Female chela weight } \\
\hline Between chelae & 3.32 & 64 & 3.18 & 0.049 & $1.28^{\mathrm{NS}}$ \\
\hline Within chelae & 3.48 & 64 & 2.49 & 0.039 & \\
\hline
\end{tabular}


Table 3 - Regression equations for individual segments of major and minor chela in relation to carapace length in male and female.

\begin{tabular}{|c|c|c|c|c|}
\hline Parameter & $\mathbf{R}$ & Intercept (a) & Slope (b) & Allometry \\
\hline \multicolumn{5}{|c|}{ Male-Major Chela } \\
\hline Ischium & $0.878 * * *$ & -0.784 & 1.366 & + \\
\hline Merus & $0.855 * * *$ & -0.133 & 1.833 & + \\
\hline Carpus & $0.829 * * *$ & -1.344 & 2.145 & + \\
\hline Propodus & $0.839 * * *$ & -1.174 & 2.104 & + \\
\hline Dactylus & $0.852 * * *$ & -1.129 & 1.632 & + \\
\hline \multicolumn{5}{|c|}{ Male-Minor Chela } \\
\hline Ischium & $0.789 * * *$ & -0.532 & 1.116 & + \\
\hline Merus & $0.764 * * *$ & -0.708 & 1.412 & + \\
\hline Carpus & $0.767 * * *$ & -0.857 & 1.627 & + \\
\hline Propodus & $0.706 * * *$ & -0.636 & 1.567 & + \\
\hline Dactylus & $0.703 * * *$ & -0.493 & 1.049 & + \\
\hline \multicolumn{5}{|c|}{ Female-Major Chela } \\
\hline Ischium & $0.818 * * *$ & -0.061 & 0.681 & - \\
\hline Merus & $0.867 * * *$ & -0.256 & 0.961 & 0 \\
\hline Carpus & $0.832 * * *$ & -0.370 & 1.145 & + \\
\hline Propodus & $0.812 * * *$ & -0.113 & 1.04 & + \\
\hline Dactylus & $0.872 * * *$ & -0.336 & 0.859 & - \\
\hline \multicolumn{5}{|c|}{ Female-Minor Chela } \\
\hline Ischium & $0.803 * * *$ & -0.014 & 0.614 & - \\
\hline Merus & $0.851 * * *$ & -0.27 & 0.927 & 0 \\
\hline Carpus & $0.883 * * *$ & -0.272 & 0.998 & 0 \\
\hline Propodus & $0.863 * * *$ & -0.089 & 0.957 & 0 \\
\hline Dactylus & $0.821 * * *$ & -0.256 & 0.746 & - \\
\hline
\end{tabular}

+ Positive allometry, - Negative allometry, 0 isometry

*** Highly significant $(\mathrm{P}<0.001)$

Segmental growth of major and minor chela with reference to the carapace length of $M$. nobilii was analyzed among sexes. Among the five segments, propodus was the longest segment followed by carpus and merus in both chelae of male and in female; ischium and dactylus was the smallest segments. In male all the segments in major and minor chela showed positive allometric growth (Table 2).

In female, carpus and propodus of major chela only showed positive isometric growth. Further merus of major and minor chela exhibited isometric growth. Growth of carpus and propodus of minor chela was also isometric. Ischium and dactylus in major and minor chelae showed negative allometric growth (Table 3). Analysis of covariance of growth of major and minor chelae segments indicated that there was a significant difference $(\mathrm{P}<0.001)$ in growth pattern between major and minor chelae in males whereas in females the growth constants of major and minor chela segments did not differ significantly
$(\mathrm{P}>0.05)$. However elevations (intercept of minor and major chela) differed significantly $(\mathrm{P}<0.001)$ (Table 4). Regarding the growth of segments of major and minor chelae in male and female, the length increment of each segment differed one from another $(\mathrm{P}<0.001)$ (Table 5).

Among sexes, carpus had a maximum allometry level, which declined to the minimum in dactylus and ischium (Fig. 2). 


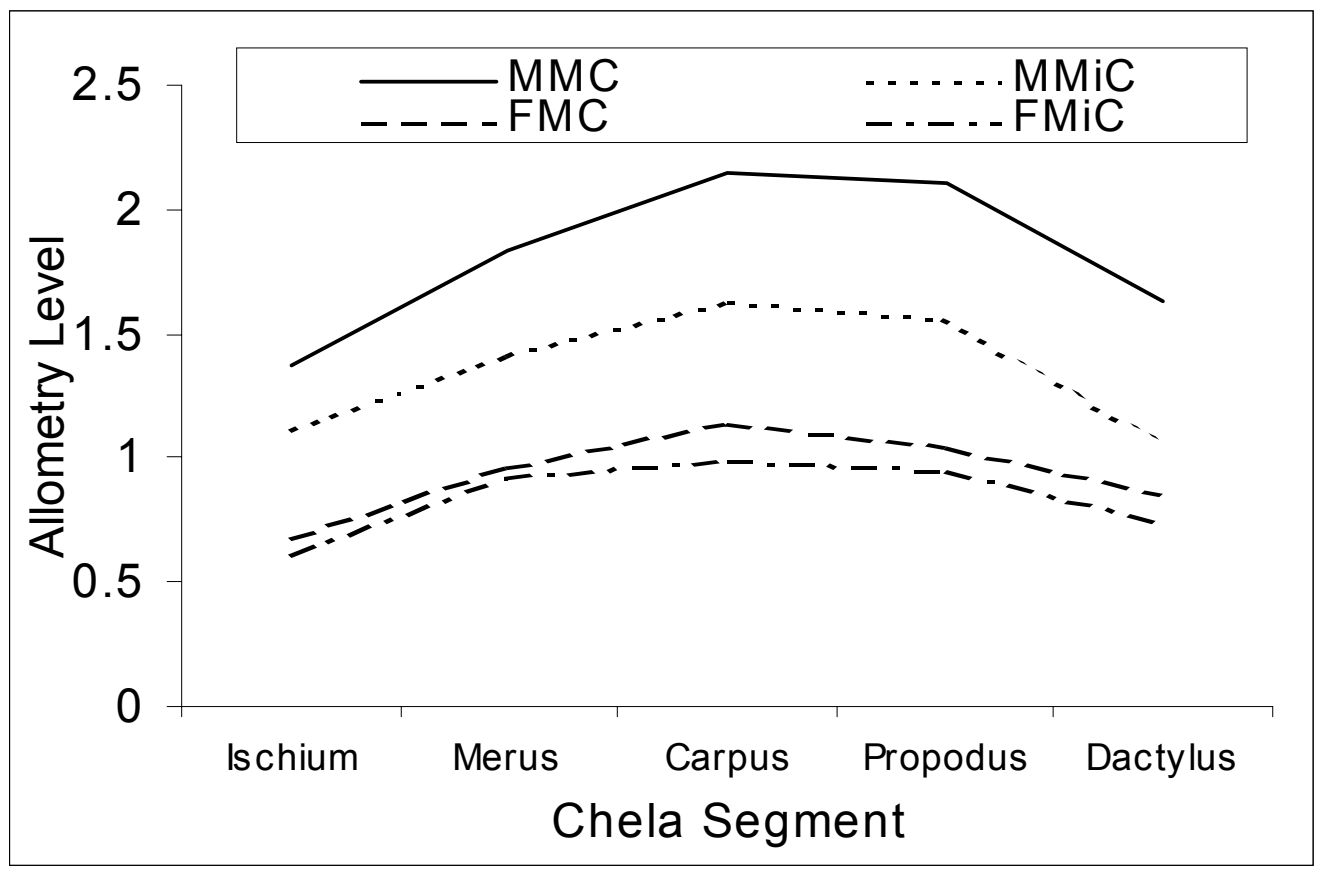

Figure 2 - Allometry levels of major and minor chela segments of male and female Macrobrachium nobilii. MMC-Male Major Chela, MMiC-Male Minor Chela, FMC-Female Major Chela, FMiC-Female Minor Chela.

Table 4 - Macrobrachium nobilii: Comparison or regression equations for individual segments (Y) of major and minor chela against carapace length $(\mathrm{X})$ in males.

\begin{tabular}{|c|c|c|c|c|}
\hline \multirow[t]{2}{*}{ Character } & \multicolumn{2}{|c|}{ Regression Equation } & \multicolumn{2}{|c|}{ Comparison of } \\
\hline & Major & Minor & Slope Value & Elevation Value \\
\hline \multicolumn{5}{|c|}{ Male } \\
\hline Ischium & $-0.783+1.366 . X$ & $-0.532+1.116 . X$ & $3.37 * * *$ & $164.89 * * *$ \\
\hline Merus & $-1.133+1.833 . \mathrm{X}$ & $-0.708+1.412 . X$ & $5.32 * * *$ & $171.31 * * *$ \\
\hline Carpus & $-1.344+2.146 . X$ & $-0.857+1.627 . \mathrm{X}$ & $4.59 * * *$ & $198.47 * * *$ \\
\hline Propodus & $-1.174+2.104 . \mathrm{X}$ & $-0.636+1.567 . X$ & $5.23 * * *$ & $127.38 * * *$ \\
\hline Dactylus & $-1.129+1.632 . X$ & $-0.493+1.049 . \mathrm{X}$ & $6.73 * * *$ & $38.69 * * *$ \\
\hline \multicolumn{5}{|c|}{ Female } \\
\hline Ischium & $-0.611+0.681 . \mathrm{X}$ & $-0.014+0.613 . X$ & $0.29^{\mathrm{NS}}$ & $61.84 * *$ \\
\hline Merus & $-0.256+0.961 . X$ & $-0.27+0927 . \mathrm{X}$ & $0.11^{\mathrm{NS}}$ & $156.94 * *$ \\
\hline Carpus & $-0.369+1.144 . X$ & $-0.272+0.998 . X$ & $1.61 *$ & $164.56^{* *}$ \\
\hline Propodus & $-0.113+1.039 . \mathrm{X}$ & $-0.089+0.957 . X$ & $0.5^{\mathrm{NS}}$ & $164.91 * *$ \\
\hline Dactylus & $-0.335+0.858 . \mathrm{X}$ & $-0.256+0.747 . X$ & $1.59 *$ & $160 * *$ \\
\hline
\end{tabular}

* Statistically significant $(\mathrm{P}<0.05): \mathrm{F}_{64,64}=1.513$

** Statistically highly significant $(\mathrm{P}<0.001): \mathrm{F}_{64,64}=2.193$

$* * *$ Statistically highly significant $(\mathrm{P}<0.001): \mathrm{F}_{70,70}=2.116$

NS Statistically not significant $(\mathrm{P}>0.05): \mathrm{F}_{64,64}=1.513$ 
Table 5 - Macrobrachium nobilii: Comparison of regression equations for individual segments (Y) of major of male against female and minor chela of male against female carapace length $(\mathrm{X})$.

\begin{tabular}{|c|c|c|c|c|}
\hline \multirow[t]{2}{*}{ Character } & \multicolumn{2}{|c|}{ Regression Equation } & \multicolumn{2}{|c|}{ Comparison of } \\
\hline & Male & Female & Slope Value & Elevation Value \\
\hline \multicolumn{5}{|c|}{ Major Chela } \\
\hline Ischium & $-0.783+1.366 . X$ & $-0.611+0.681 . X$ & $42.15 * * *$ & $196.6^{* * *}$ \\
\hline Merus & $-1.133+1.833 . X$ & $-0.256+0.961 . X$ & $36.44 * * *$ & $241.31 * * *$ \\
\hline Carpus & $-1.344+2.146 . X$ & $-0.369+1.144 . \mathrm{X}$ & $27.27 * * *$ & $250.09 * * *$ \\
\hline Propodus & $-1.174+2.104 . X$ & $-0.113+1.039 . X$ & $53.86^{* * *}$ & $275.56 * * *$ \\
\hline Dactylus & $-1.129+1.632 . \mathrm{X}$ & $\begin{array}{r}-0.335+0.858 . X \\
\text { Minor Chela }\end{array}$ & $19.63 * * *$ & $78.31 * * *$ \\
\hline Ischium & $-0.532+1.116 . X$ & $-0.014+0.613 . X$ & $9.36^{* * *}$ & $98.66^{* * *}$ \\
\hline Merus & $-0.708+1.412 . \mathrm{X}$ & $-0.27+0927 . \mathrm{X}$ & $10.22 * * *$ & $244.32 * * *$ \\
\hline Carpus & $-0.857+1.627 . X$ & $-0.272+0.998 . X$ & $14.86^{* * *}$ & $253.91 * * *$ \\
\hline Propodus & $-0.636+1.567 . X$ & $-0.089+0.957 . X$ & $10.87 * * *$ & $253.79 * * *$ \\
\hline Dactylus & $-0.493+1.049 . X$ & $-0.256+0.747 . \mathrm{X}$ & $4.87 * * *$ & $247.18 * * *$ \\
\hline
\end{tabular}

*** Statistically highly significant $(\mathrm{P}<0.001) \mathrm{F}_{70,64}=2.166$

\section{DISCUSSION}

Length-weight relationship study is a useful index to measure the variation in the growth of individual prawn or group of prawns (Jayachandran and Joseph, 1988). Variation in the length weight relationship obtained between the male and female of $M$. nobilii was due to the variation in food, population density, environmental conditions and genetic make up of the species which has been well documented in earlier studies (Abrahamson, 1966; Kuris et al., 1987). In decapod crustaceans, morphometric studies have been widely used for taxonomic purposes in the genus Macrobrachium (Tesch, 1915; Holthuis, 1950; Koshy, 1969; Jayachandran and Joseph, 1988; Chace and Bruce, 1993; Suzuki and Kusamura, 1997); in brachyura (Davidson and Marsden, 1987; Clayton, 1990; Abello et al., 1990); in spiny and clawed lobsters (Aiken and Waddy, 1980). It is well known that Macrobrachium is a more confusing genus. Recently, Jayachandran (1998) differentiated some closely related species of Macrobrachium on the basis of the relative growth of second pereiopods. Like other crustacean groups the growth of male cheliped had a positive allometry with reference to the cephalothoracic length but in females it was isometric. Such variations in allometric level are well documented in Brachyura. The enlarged chelae in males are related to the vital social interactions like territorial defense, combat, display and courtship. The use of such enormous sized chelae in decapods are many viz; signaling display by male Uca (Crane, 1975), carrying females during courtship in male Corystes (Hartnoll, 1968), inter male combat in non brachyurans like Caprella gorgonia (Lewbel, 1978); Macrobrachium rosenbergii (Barki, 1991), M. australiense (Lee and Fielder, 1983), burrow protection in Alpheus heterochaelis (Conover and Miller, 1978); holding the female during copulation in Orconectes propinquus (Stein, 1976) and protecting the defenseless female just after premating moult in $M$. nobilii (Balasundaram, 1980).

Among the closely related species of Macrobrachium such as M. malcolmsonii and $M$. birmanicum, though the ratio between merus and palm, carpus and chela, and fingers and palm were the same, in M. malcolmsonii, the carpus was longer than the palm while it is shorter in $M$. birmanicum (Jayachandran, 1998). In M. nobilii, the carpus was shorter than the propodus while the level of allometry was higher when compared to propodus. Koshy (1973) and Nagamine and Knight (1980) also made similar findings in $M$. dayanum and $M$. rosenbergii, respectively where the propodus was longer than the carpus. In $M$. rosenbergii, three male morphotypes (i.e) BC-Blue Clawed Males, OC-Orange Clawed Males and SM-Small Males were differentiated on the basis of the total length of chela (Kuris et al., 1987). Further BC males were distinguished from OC males from the variations in length of carpus and propodus. The propodus had a positive allometric $(\beta=1.26)$ while the growth of carpus was isometric $(\beta=1.09)$ (Kuris et al., 1987). In male M. nobilii, the growth of propodus and carpus had positive allometry. In females it was isometry for major 
and minor chela. Comparison of allometric levels in different crustacean species were indicated, its variations were as a function of sex and even within females of Trapezia ferruginea, allometric level was negative in normal while it was positive among berried females (Finney and Abele, 1981). Huxely (1932) developed a growth gradient concept by studying the growth pattern of a series of organs or segments of an organ. In this line the best known examples are the studies on the patterns of growth of a) individual segments of a limb, b) the segments of the body and c) the sequence of limbs along the body (Hartnoll, 1982). Huxley (1932) observed a growth center in chelipeds of species like Uca pugnax, Maja squidao and Macrobrachium rude (=Palaemon rudis) where the maximum allometry level was at propodus, which decreased towards dactylus and coxa. Dawes (1934) observed such a growth center in propodus of Alpheus dentipes but Asellus aquaticus it was in propodus or carpus (Needham, 1943). In Ocypode aegyptica and Eriocheir sinensis two growth centers have been reported (Sandon, 1937). In the right chela of male Pagurus bernhardus the growth gradient changed from the merus to propodus when the crab grows (Huxley, 1932). In this study the maximum allometry level in M. nobilii was recorded in carpus in both chelae and both sexes. Presence of sexual dimorphism in second pereiopod in M. nobilii was an agreement with the earlier findings in related species such $M$. rosenbergii (Nagamine and Knight, 1980), M. malcolmsonii (=Palaemon malcalmsonii) (Patwardhan, 1937) and M. dayanum (Koshy, 1973). From this study we concluded that the studied morphometric characters could be used to describe the species.

\section{ACKNOWLEDGEMENTS}

PM is grateful to CSIR-India for the award of Senior Research Fellowship and Senior Research Fellowship (Extended), Prof. K.V. Jayachandran, Kerala Agricultural University for his critical review of this MS and P. Balamurugan for his valuable helps in MS preparation.

\section{RESUMO}

Quatorze características morfológicas do Macrobrachium nobilii (Henderson e Matthai, 1910), 72 machos e 66 fêmeas de lagostas de água fresca foram medidas. O crescimento constante (b) do comprimento total e peso para os machos (4.28) e fêmeas (3.02) apresentaram diferenças significativas $(\mathrm{P}<0.05)$. A comparação da inclinação e da elevação das regressões entre sexos indicaram diferenças significativas em todos os parâmetros dependentes estudados comprimento da carcaça (x), exceto largura da carcaça (y). Nos machos, as garras principais e secundárias demonstraram alometria positiva quando nas fêmeas o crescimento foi isométrico.

\section{REFERENCES}

Abello, P.; Pertierra, J. P. and Reid, D. G. (1990), Sexual dimorphism, relative growth and handedness in Liocarcinus depurator and Macropipus tubercilatus (Brachyura: Portunidae). Scientia Marina, 54,195-202.

Abrahamsson, S. (1966), Dyanamics of an isolated population of the crayfish Astacus astacus (Linne) and Pasifastacus leniusculus (Dana). Svensk Naturvetenskap, 1964, 306-316.

Aiken, D. E. and Waddy, S. L. (1980), Maturity and Reproduction in the American lobster. Can. Tech. Rep. Fish. Aquat. Sci., 932, 59-71.

Balasundaram, C. (1980), Ecophysiological studies in prawn culture (Macrobrachium nobilii). Ph.D. Dissertation - Madurai Kamaraj University, India.

Barki, A.; Karplus, I. and Goren, M. (1991), Morphotype related dominance hierarchies in males of Macrobrachium rosenbergii (Crustacea, Palemonidae). Behaviour, 117, 145-160.

Chace, F. A. and Bruce, A. J. (1993), The caridean shrimps (Crustacea, Decapoda) of the Albatross Philippine Expedition, 1907-1910, part 6 Superfamily Palaemonidae. Smithsonian Contribution to Zoology, 543, 1-152.

Clayton, D. A. (1990), Crustacean allometric growth: a case for caution. Crustaceana, 58, 270-290.

Conover, M. R. and Miller, D. E. (1978), The importance of large chela in the territorial and pairing behaviour of the snapping shrimp, Alpheus heterochaelis. Mar. Behav. Physiol., 5, 185-192.

Crane, J. (1975), The fiddler crabs of the world (Ocypodidae: Genus Uca). New Jersey : Princeton University Press. 
Davidson, R. J. and Marsden, I. D. (1987), Size relationships and relative growth of the New Zealand swinming crab Ovalipes catharus (White, 1843). J.Crust. Biol., 7, 308-317.

Dawes, B. (1934), A study of normal and regenative growth in pistol shrimp, Alpheus dentipes (Guerin). Wilhelm Roux' Entwicklungsmech. Org., 131, 543-574.

Finney, W. C. and Abele, L. G. (1981), Allometric variation and sexual maturity in the obligate coral commensal Traperia ferruginea Latreille (Decapoda, Xanthidae). Crustaceana, 41, 113-130.

Grandjean, F. A.; Romain, D.; Avila-Zarza, C.; Bramard, M.; Sout-Grosset, C. and Mocquard, J. P. (1997), Morphometry, sexual dimorphism and size at first maturity of the white clawed crayfish, Austropotambius pallipes pallipes (Lereboullet) from a wild French population at Deux-Sevres (Decapoda, Astacidae). Crustaceana, 70, 31-44.

Hartnoll, R. G. (1982), Growth. In: Abele, L. G. (ed.). The Biology of Crustacea. New York : Academic Press. pp. 111-196.

Hartnoll, R. G. (1978), The determination of relative growth in crustacea. Crustaceana, 34, 281-293.

Hartnoll, R. G. (1968), Reproduction in the burrowing crab, Corystes cassivelaunus (Pennant, 1777) (Decapoda, Brachyura). Crustaceana, 15, 165-170.

Holthuis, L. B. (1950), The Palaemonidae collected by the Siboga and Snellius expeditions, with remarks on other species. I. Subfamily Palaemoninae. Siboga Exped., 39, 1-268.

Huxely, J. S. (1932), Problems of relative growth. Methuen, London.

Jayachandran, K. V. (1998), The taxonomic status of Macrobrachium birmanicum (Schenkel) and $M$. choprai (Tiwari) with a note on closely related species. Indian J. Fish., 45 : (3), 345-348.

Jayachandran, K. V. and Joseph, N. I. (1988), Lengthweight relationship of two Palaemonid prawns Macrobrachium idella and M. scabriculm. A comparative study. Fishery Technology, 25, 189-195.

Jayachandran, K. V.; Indira, B.; Korath. A. and Malika, V. (1996), Detailed morphometric studies in Penaeus indicus Milne Edw. From Veli Lake, Trivandrum. Proc. Indian Natn. Sci. Acad., B62, 65-70.

Koshy, M. (1973), Studies on the sexual dimorphism in the freshwater prawn Macrobrachium dayanum (Henderson, 1893) (Decapoda, Caridea), II. Crustaceana, 24, 110-118.

Koshy, M. (1971), Studies on the sexual dimorphism in the freshwater prawn Macrobrachium dayanum (Henderson, 1893) (Decapoda, Caridea), 1. Crustaceana, 21 : (1), 72-78.

Koshy, M. (1969), Studies on the sexual dimorphism in the freshwater prawn Macrobrachium lamarrei $(\mathrm{H}$. Milne Edwards, 1837) (Decapoda, Caridea). Crustaceana, 16, 185-193.
Kunju, M. M. (1978), Growth in prawns. In: Proceedings of the Summer Institute in Breeding and Rearing of Marine Prawns. Cental Marine Fisheries Research Institute, Cochin India Special Publication. pp. 48-57.

Kuris, A. M. and Carlton, J. T. (1977), Descriptions of a new species, Crangon handi, and new genus, Lissocrangon, of crangonid shrimps (Crustacea: Caridea) from the California coast, with notes on adaptation in body shape and coloration. Biol. Bull., 153, 540-559.

Kuris, A. M.; Ra'anan, Z.; Sagi, A. and Cohen, D. (1987), Morphometric differentiation of male Malaysian giant prawns, Macrobrachium rosenbergii. J. Crust. Biol., 7, 219-237.

Lee, C. L. and Fielder, D. R. (1983), Agonistic behaviour and the development of dominance hierarchies in the freshwater prawn, Macrobrachium australiense Holthuis, 1950. (Crustacea: Palaemonidae). Behaviour, 83, 1-17.

Lewbel, G. S. (1978), Sexual dimorphism and intraspecific aggression, and their relation to sex ratio in Caprella gorgonia Laubitz and Lewbel (Crustacea,Amphipoda, Caprellidae). J. Exp. Mar. Biol. Ecol., 33, 133-151.

Mariappan, P.; Balamurugan, P. and Balasundaram, C. (2003), Freshwater prawn, Macrobrachium nobilii (Henderson and Matthai, 1910): a promising candidate for rural nutrition. Aquaculture Asia [In Press].

Mariappan, P.; Balamurugan, P. and Balasundaram, C. (2002), Diversity and utilization of freshwater prawns (Macrobrachium) in River Cauvery in Tamil Nadu. Zoos Print Journal, 17 : (10), 919-920.

Mariappan, P. and, Balasundaram, C. (1999), Hunting grounds for freshwater prawn seed. Science Express, The New Indian Express, July $13^{\text {th }}$ Issue, pp. 2.

Mossolin, E. C. and Bueno, S. L. S. (2003). Relative growth of second pereiopod in Macrobrachium olfersi (Wiegmann, 1836) (Decapoda, Palaemonidae). Crustaceana, 76, 363-376.

Muino, R.; Fernandez, L.; Gonazalez-Gurraiaran, E.; Freire, F. and Vilar, J. A. (1999), Size at maturity of Liocarcinus depurator (Brachyura: Portunidae): a reproductive and morphometric study. J. Mar. Biol. Asso. U.K., 79, 295-303.

Nagamine, C. and Knight, A. W. (1980), Development, maturation and function of some sexually dimorphic structures of the Malaysian prawn, Macrobrachium rosenbergii (de Man) (Decapoda, Palaemonidae). Crustaceana, 39, 141-152.

Needham, A. E. (1943), On the relative growth in Asellus aquaticus. 2. Proc. Zool. Soc. London. Ser A. 113, 44-75.

Patwardhan, S. S. (1937), Palaemon. Indian Zool. Mem., 6, 1-120. 
Pinheiro, M. A. A. and Fransozo, A. (1998), Sexually maturity of the specked swimming crab Arenaeus cribrarius (Lamark, 1818) (Brachyura, Portunidae), near Ubatuba, State of São Paulo, Brazil. Crustacena, 65, 377-389.

Sandon, H. (1937), Differential growth in the crab Ocypod. Proc. Zool. Soc. London, 107, 397-414.

Sarda, F. and Cartes, J. E. (1997), Morphological features and ecological aspects of juvenile specimens of the aritsteid shrimp Aristeus antennatus (Risso, 1816). Mar. Freshwater Res., 48, 73-77.

Snedecor, G. W. and Cochran, W. G. (1967), Statistical Methods. Oxford and IBH Publishing Co. Pvt. Ltd. New Delhi.

Sokal, R. R. and Rohlf, F. J. (1981), Biometry. New York : W. H. Freeman.

Stein, R. A. (1976), Sexual dimorphism in crayfish chelae: functional significance linked to reproductive activities. Can. J. Zool., 54, 220-227.

Sumpton, W. D. (1990), Morphometric growth and fisheries biology of the crab, Charybdis natator (Herbst) in Moreton Bay, Australia (Decapoda, Brachyura). Crustaceana, 59, 113-120.

Suzuki, H. and Kusamura, T. (1997), Reexamination of the diagnostic characters of two freshwater palaemonid prawns, Macrobrachium nipponense (De Haan, 1849) and M. formosense Bate, 1868 (Decapoda, Caridae) from Japan. Crustaceana, 70, 831-839.

Tesch, J. J. (1915), The catometopous genus Macopthalmus as represented in the collection of the Leiden Museum. Zool Meded. Leiden, 1, 149-204.

Tessier, G. (1960), Relative growth. In: Waterman, T. H. (ed.). The physiology of crustacea. Metabolism and growth. New York: Academic Press. pp. 537-560. v. 1. 